\title{
Determinants of Business Linkage Between Medium-Small and Large Business Enterprises in Manufacturing Sector: The Case of Kombolcha City
}

\author{
SEID MOHAMMED ${ }^{1} \quad$ HASSEN BESHIR $^{2}$
}

\begin{abstract}
The Medium and Small Enterprises (MSE) sector in Ethiopia is faced with many challenges and constraints including business linkages with large enterprises. Business linkages give MSEs the opportunity to participate as suppliers, distributors or retailers in commercial value chains which can help increase local job and wealth creation, enhance skills and capacity, add purchasing power and generally stimulate economic activity and developmentcontributing in the process, to quality of life. Despite the critical roles played by the business linkages in distributor MSEs in the textile sub-sector, they have been experiencing determinants leading to low-performance or limited linkage with large enterprises. This study was conducted in Amhara region, south wollo zone, Kombolcha city. The main purpose of this study was to explore the basic determinant factors of business linkages between MSEs and large firms in textile sub-sector in Kombolcha town. The population of this study was 71 MSEs and 1 large enterprise. Census method was used to conduct the research throughout enterprises in textile sub-sector and primary data was collected with the use of Self-administered questionnaire and key informant interview. The researcher had used mixed approach that was both qualitative and quantitative methods to identify and analyze determinants. Descriptive statistical methods and logit regression model supported by qualitative analysis had been employed SPSS and STATA software to analyses the collected data. The result showed that the business linkage between small and large business in Kombolcha city particularly in textile sub-sector was found limited. MSEs in Kombolcha city are facing a lot of problems that hinder their business linkage; lack of raw materials is the most series problem. Determinants such as education levels, raw materials, technology, training, and leadership were found significant that affect business linkage positively. Therefore the study suggest that improving educational levels of MSEs owners, availability of raw materials, training like technical and managerial skills, giving attention to assure capable and committed leadership and for the future intervention strategies aimed at the mutual benefit between MSEs and large enterprises and technological transformation to strengthen business linkage. The government and private sectors are expected to exert strong effort to create business linkage between MSEs and large businesses in textile sub-sector.
\end{abstract}

Keywords: - Business linkage, Determinants, MSEs, Large, Enterprises

DOI: $10.7176 / \mathrm{JESD} / 10-3-08$

\section{INTRODUCTION}

\subsection{BACKGROUND OF THE STUDY}

According to Federal Micro and Small Enterprise development agency,(2011), the Ethiopian economy, although still highly dominated by the Agricultural Sector in terms employment (80\%), its contribution to the GDP (44\%) and its share in the export market (80\%), is witnessing one of the fastest growing economies in Africa as well as in the world. The Ethiopian government issued the new Micro and Small Enterprises (MSE) development strategy (2011). In this strategy the Government of Ethiopia has given greater focus for the development of manufacturing sector that encompasses the MSEs Sector in order to realize industrialization. On top of providing jobs to the people, the establishments are also hoped to bring about the technological transfer and new corporate management skills to the nation. The growth stages of the MSEs are three in number and they are: the start-up stage, the growth stage and the maturity stage.

AACCSA, (2014), the number of manufacturing sector in Ethiopia was 2,610 in 2012/13 which is still at its infancy and the low productivity. Hence the competitiveness of the manufacturing industry has been largely attributed to a variety of reasons, the major ones being the sector's use of obsolete machinery, lack of skilled man power and application of backward production technology. In order to enhance its productivity, the sector has to address its critical obstacles. From the industry sub-sector, the manufacturing firms in Ethiopia were utilizing only 54.3 percent of their production capacity. In other words, 45.7 percent of the total capacity remained unexploited. The main reasons for the observed under capacity utilization rate differ from time to time. Michael W. Hansen, et al., (2016), stated that the future of Africa development lies to a large extent in the hands of its indigenous MSEs. These are the firms that will create most of the private sector jobs for rapidly growing labor force. These are the firms that will meet surging African demand for products and services. These are the firms where local

\footnotetext{
1 Seid Mohammed is a senior public participation officer at South Wollo in Ethiopia, Email: seid2384@gmail.com

2 Hassen Beshir is Associate Professor in Agricultural and Applied Economics at Wollo University in Ethiopia
} 
entrepreneurial talent will grow and realize itself. And these are the firms that will become the future champions of African industry. Since SMEs cover more than 95 percent of all firms in Sub-Saharan Africa, and since the region consists of a large number of countries at widely different development stages and with large differences in industrial structure, it is necessary to narrow the focus of the report.

Tarfasa et al., (2014), in Ethiopia, the share of formal employment increased in urban areas, while informal employment declined from 4.3 percent in 2005 to 3.2 percent in 2013 , declined by 1.1 percentage points. In 2005 , of the 4.0 million employed people living in urban areas, 1.32 million were employed in the informal sector, and the same figure increased to 1.33 million in 2013. This implies that while there are still a large number of workforces employed in the urban informal sector, it has not grown significantly since 2005 . This evidence/figure confirms that although a focus on broad-based growth and transformation through the promotion of MSEs has been underscored in various development plans, both the level of unemployment and quality of jobs remain a concern in Ethiopia. MSEs have been performing below capacity and their growth has been severely constrained by a number of factors.

Charles M., et al., 2016; Lenaerts, Merlevede, 2011, linkages can also be defined as channels through which enterprises influence each other's economic performance. They show the interrelationship among various economic activities through the input-output relationships or the economic value chain. Final demand linkages have to do with the incomes generated in the domestic economy by the Enterprise. Amendolagine et al, (2013), linkages between Large Enterprises and MSEs are important in the context of investment for development. The spillovers of know-how and technology from large firm which are usually foreign-invested enterprises to the rest of the business sector is one of the main benefits of FDI to development. According to Bwisa (2011) businesses must build networks if they are to become more competitive. Networking is a process of creating alliances with people and alliances beyond the immediate boundaries of the venture. It is a process of linking up with the right people to get things done and the difference between a successful and unsuccessful venture often rests in knowing people in the right places. MSEs, linkages with large firms help Micro and Small Enterprises (MSEs) to learn new and better production methods and can help to increase MSE employment.

However, in Ethiopia in practice the vast majority of MSEs remain de-linked from large enterprise, missing these potential opportunities. Many large enterprises assert that there is a lack of suitable local MSEs partners that could meet their large or corporate standards or international product standards. For most local MSEs, "partnership readiness", a prerequisite for mutually beneficial linkages with large enterprises, often remains an elusive objective because MSEs faced different problems which are associated with personal, socio-economic, challenges, government support constraints and determinants factors that hinders business linkage MSEs with large enterprises. To take appropriate measures for these problems, knowing the determinant factors associated with the problems is a precondition for a problem well stated is half solved. Therefore, the aim of this research is to identify the major determinant factors that affect the business linkage between MSEs and large textile enterprises in Kombolcha town in developing mutual benefit and recommend the appropriate measures to be taken.

\subsection{STATEMENT OF THE PROBLEM}

James et al, (2014), the various business linkages that the micro and small enterprises (MSEs) can establish with large enterprises are essential factors for their growth and competitiveness. The organization of these linkages is crucial both up-stream with the suppliers and sub-contractors, and down-stream with the distribution and marketing channels. APEC, PERU (2016) stressed that to promote the MSEs' participation in GVCs, indirect linkages of MSEs with larger domestic firms are important. Amendolagine et al, (2013), the benefits stemming from business linkages crucially depend on density, depth and nature of supplying and buying linkages between the large investors and local small firms. Ndemo \& Smallbone, (2015), closer integration, openness to trade and business linkages are helping firms in developing countries become part of international production networks and global value chains, thereby creating new sources of growth and development worldwide. UNCTAD, (2010), evidence shows that linkages expansion and trade liberalization need to be accompanied by a coherent policy framework both at the national and global level, enabling enterprise development and the integration of domestic markets into global markets. Ndemo and Smallbone, (2015), many transition and developing countries in particular, face a need to promote and strengthen the long term development of the MSE sector, which requires access to market opportunities, new technology and management know-how, often in a situation of considerable resource scarcity.

European Journal of Business Management,(2014), in Africa business linkages between SMEs and large enterprises are remain largely underdeveloped and isolated thus leading to inadequate technological transfer and development, poor information flow, weak sub contracting arrangements and inadequate marketing opportunities to promote expansion and growth of SMEs. Ethiopian Industrial Development Strategic Plan (2013-2025), (2013), stated that in Ethiopia most of MSEs faced with many challenges and constraints including business linkages with large enterprises. The Partnership of most MSEs with local industries, multinational companies and global firms are de-linked and also critical for the realization of industrialization. CSOM, (2016), the basic determinants of 
business linkage between MSEs and large enterprises are lack of horizontal and vertical linkages in value chains, lack of information, lack of technological capability, Protectionism, lack of trade liberalization and attracting FDI, dependence on imported materials, insufficient policy support and poor business environment. AACCSA, (2015), the Ethiopian MSEs in current period is highly influenced by the lack of integration among MSEs themselves and with other external large enterprises starting from resources like lack of raw materials availability, insufficient government support to manufacturing sector training, infrastructure and MSEs constraints, customers, inadequate marketing opportunities, financial institutions and with others stakeholders.

Thus, determinant factors can be categorized as internal determinants factors (sex of enterprises owner, level of education, experience of enterprise, training, information, employee and family size of enterprise) and external determinant factors (raw materials, technology, finance, work space, administrative leadership style, working capital, infrastructure and existence of related large factories) that affect business linkage between MSEs and Large enterprises were required a detailed evaluation process how determinants affect the performance of integrating MSEs with large enterprises. Those researchers discuss above put their effort on analyzing the effect of business networking in maximizing performance of MSEs and solving problem related to their business operation. To the contrary, in Ethiopia, most of these studies focused on studying the performance of small and medium sized enterprises, role of MSEs on the employment, income generation and job creation, challenges and barriers of MSEs growth, the networking practice and problems of enterprises as a general without focusing on determinants which affect business linkage between MSEs and large enterprises is not yet fully understood and evaluated. According to Kombolcha TVED office annual report, (2016) states that micro, small textile enterprises and kombolcha Textile Share Company are de-linked. This research have been conducted based on three reasons first MSEs in textile subsector after establishment there were limited support or follow up from government and private sectors. In this regard the researcher also for the last five year has been observing the real challenges that MSE's faced in the study area. Secondly, the government by itself has recommended the issue of "linkage" between micro, small and large textile enterprises as a prioritized area within industrial development strategic plan (2013-2025) for further study. Thirdly, Kombolcha city was already selected for textile and garment cluster. Therefore, this study is deemed to fill the gaps by examining determinants that affect to create business linkage between MSEs and large enterprises become crucial particularly in textile subsector in kombolcha city. Furthermore, the supports which are given by public and private institutions to integrating MSEs with large enterprises are assessed very well.

\subsection{RESEARCH QUESTIONS}

Thus, the study attempts to answer the following basic questions:-

- What are the opportunities and challenges of enterprises in creating business linkage?

- To what extent the government is supporting the MSE to integrate $\mathrm{w}$ ith the large business?

- What are the major determinants that affect linkages between small and large business?

\subsection{RESEARCH OBJECTIVES}

\subsubsection{General Objective}

The general objective of the research was to determine the basic determinants of business linkage between MSEs and large business in textile sub-sector at kombolcha city.

\subsubsection{Specific Objectives}

The specific objectives of the study were:

- To describe opportunities and challenges of MSEs in creating business linkages in textile sub- sector.

- To asses government support in integrating MSEs with large enterprises.

- $\quad$ To examine the determinant factors in creating business linkage between small and large business.

\subsection{SIGNIFICANCE OF STUDY}

The research had identified the existing challenges and opportunities in creating business linkage and the determinant factors that affect the relationship between MSEs and large enterprises in textile subsector. The findings will help policy makers and the new establishing industry cluster institutions to be informed about the main determinants of business linkage and the associated challenges. From the finding the Amhara region, south wollo zone and Kombolcha town also will be benefited to create sustainable business linkage and establish strong coordination system among MSEs and large enterprises through joint planning and evaluation system. Such system had been used to cultivated new enterprises, enhancing the capacities of the existing enterprises and kombolcha technical vocational and enterprises development office effort in supporting MSEs would be fruitful. This can help both MSEs and large enterprises to effectively address the existing problems in creating business linkage and to exploit the opportunities of horizontal and vertical business linkages to achieve sustainable growth and, consequently unemployment would be reduced, the local economy grows and the society in large would get benefited. Taking the relationship between business linkage and the various independent factors, other researchers could use the research as a basis for making further investigation. 


\subsection{DELIMITATIONS OF THE STUDY}

Information taken from kombolcha technique vocational and enterprises development office showed that 71 MSEs textile enterprises were found in the town. Had the study been conducted in all of them, it would have been complete. Furthermore, there were different issues that can be researched in business linkage between small and large enterprises. But, this study was delimited to the key industrial cluster, socio-cultural factors affecting the performance of business linkage between small and large enterprises in textile subsector.

In addition, the study focused only on assessing the major determinants between MSEs and large enterprises in textile subsector to check whether these determinants affect their business linkage. The study also addressed the availability of sex, family, employees, education, experience, raw materials, working capital, leadership style, information, existence of large related enterprises, amount of finance, technology, training, workspace, and infrastructure(support) from government and private sector (kombolcha textile Share Company) to MSEs and large enterprises to create business linkage in textile subsector face.

\subsection{LIMITATION OF STUDY}

Due to time and financial constraints the research was only conducted in Kombolcha city in manufacturing sector particularly in textile sub-sector. Therefore, the research finding may not be generalized to other industry, sectors and cities.

\subsection{ORGANIZATION OF STUDY}

This study has four chapters. The first chapter was about introduction of the research. In the introductory part background of the research, statement of the problems, research questions, objectives, significances of the research, the hypotheses, limitations, delimitations, and organization of the study are included. Chapter two presents research methodology of the study that includes research design, research approach, sample design, Data collection techniques/data \& instrumentation, population and sample, description of the variables, ethical Consideration, method of data analysis and model specification for the study. Chapter three presents data presentation, analysis and interpretation. While in chapter four the summary, conclusion and recommendations drawn from the study depending upon the finding of the study was presented.

\section{RESEARCH METHODOLOGY INTRODUCTION}

In this chapter the research design used, research approach, sample design, source of data, the data gathering techniques and instrumentation, sampling and sampling procedures and the methods of data analysis are discussed very well.

\subsection{Site SELECTION AND DESCRIPTION}

The study would be conducted in Kombolcha city. The researcher has selected Kombolcha City to conduct the research. The City is selected due to its convenience for the researcher and due to more concentration of large enterprises and MSEs relative to other towns. Kombolcha town is located in northern Ethiopia, in Amhara National Regional State, South Wollo Zone, at a distance $377 \mathrm{Km}$ from Addis Ababa, and $505 \mathrm{Km}$ from Bahirdar- the regional capital. Kombolcha is one of industrial zone/cluster in Ethiopia. According to Ethiopian Central statistical agency projection (2017), the population of the City is estimated about 143,637. It is claimed that the Amhara government in general and Kombolcha administration in particular had given focus to the expansion of MSEs.

In Kombolcha City there are about 2284 registered and active MSEs out of which 210 in manufacturing sector. There are about 71 MSEs engaged in textile works. The manufacturing sector in the City includes: wood work, metal and engineering, textile, leather and leather products, hand craft, food and beverage, and agro processing in the city.

\subsection{Research Design}

Descriptive survey research design was employed in the study to assess the basic determinants that affect the business linkage between MSEs and large textile factories in kombolcha city. The reason for using this design is that it enables to describe the determinants that affect the linkage between MSEs and large business. The study helped in obtaining pertinent and precise information as well as to draw valid conclusion about the target population in manufacturing textile sector as they exist.

\subsection{Research Approach}

Methodologically the researcher was employed mixed approaches that were both qualitative and quantitative research methods adopted with the aim of asses' determinants of business linkage between MSEs and large enterprises. Quantitative data will be analyzed using descriptive statistics and logistic regression models. Moreover, to analyze the qualitative data content analysis method is used. 


\subsection{Sample Design}

The Kombolcha town was purposively selected since MSEs and large factories were, densely populated in this town while their business linkage was limited.

According to records of the Kombolcha Technical vocational and enterprises development office latest data in kombolcha town there are 2284 registered and active MSEs out of which 210 in manufacturing sector. About 71 Micro, small and 1 large enterprises were engaged in textile sub-sector. So, the researcher considered the method of approaching the entire MSEs in manufacturing textile sub-sector in the study area as appropriate. Hence, taking sample out of such population would not be advisable and desirable. Therefore, the data were to be collected from all MSEs which were engaged in Textile sub-sector. Top officials of these institutions (Kombolcha technical vocational and enterprise development office head, textile share company manager, TVET dean, Micro finance manager, MSEs one shop centers representatives and Core process owner) were purposely chosen and interviewed to triangulate data collected from enterprises owners. As researcher believes that they know better about determinants of business linkage between MSEs and large enterprises than others because of their day -to- day Follow up and contacts with MSEs and large enterprises.

Table 17. Number of Textile enterprises in Kombolcha City

\begin{tabular}{|c|c|c|}
\hline Key Enterprises & Textile & Remrk \\
\hline Micro & 65 & \\
\hline Small & 6 & \\
\hline Large & 1 & \\
\hline Total & 72 & \\
\hline
\end{tabular}

Source: Kombolcha TVED Office annual report (2008E.C)

\subsection{Source of data}

Data is obtained from primary and secondary sources. Primary data was collected from MSEs owners by distributing questionnaires. Interviews was conducted with Kombolcha technical vocational and enterprises head, Textile share company manager, TVET College dean, Micro finance institution manager, and MSEs one shop centers representatives. Organizations selected for conducting interviews are based on their role and contribution to MSEs and hence business linkages. Secondary sources were obtained from the reports of Kombolcha technical vocational and enterprises development office, TVET institution, Micro finance institution, Kombolcha Textile Share Company annual reports.

\subsection{Data collection techniques/data \& instrumentation}

Questionnaire, key informant interview and document analysis were the instruments used to collected data. By using structured questionnaire data collected from MSES and large enterprise's members, owner-managers and stakeholders. The questionnaire prepared in English then translated to Amharic. It was close and open ended with preferred over the other methods and also it was pre-coded and distributed to all textile MSEs and large enterprises by going to their work place. In addition interviews, semi-structured interview was carried out as data gathering instrument to secure important and in-depth information from MSE's Leaders, public organization and large enterprise representatives, so as to identify their roles in facilitating business linkages. The key stockholders, large business institution and government office representatives were selected and then conducted the interview so as to get in-depth information.

\subsection{Method of Data Analysis}

Questionnaires were first gathered, and then data was collected, edited, coded and entered into computer software SPSS and STATA. Then the final analysis of quantitative data was done using the help of version 20, SPSS, version 12, STATA and the qualitative data analyzed using coding. The descriptive statistics such as percentage, mean, frequency distributions used to analyze data obtained through close-ended questionnaire regarding to determinants of business linkage between MSEs and large enterprises. After the data encoded were completed Counting percentage, frequencies, cross-tabulations, average, mean, and logit regression model was used to analyze the quantitative data with the assistance of SPSS and STATA. The analyzed data summarized and presented by using pi-charts, bar graphs, and tables. At each stage of discussions secondary information obtained from different sources are added to make triangulate the survey analysis of determinants business linkage between MSEs and large enterprises in textile manufacturing sector in the case of Kombolcha town.

The survey also employed interpretive analysis technique in order to analyze qualitative data. The interpretation of qualitative data limited to descriptive narratives in order to complement the quantitative data. Thus, non-quantifiable data was obtained from different sources analyzed qualitatively in this way and it was used mainly to triangulate the quantitative data.

\subsubsection{Descriptive Statistics}

The study used descriptive statistics to compare and analyze using tables, graphs, percentages and mean values as 
analytical tools

\subsubsection{Econometrics Model specification}

The researcher applied logistic regression model to analyze the determinants of linkage between MSEs and large enterprises engaged in textile sub-sector. The dependent variable was whether there exist business linkage or not among enterprises. The general model was a dichotomous choice model involving estimation of the probability of participation of enterprises in the market $(\mathrm{Y})$ as a function of a vector of explanatory variables $(\mathrm{X})$. The linear probability model (LPM), even though computationally and conceptually simpler and easier than the binary choice models, it depends on the use of ordinary least squares (OLS) approach. Application of OLS however, inherently produces hetroscedastic disturbance term ( $\varepsilon i)$ and as a result, the standard deviations of the estimates are biased. These inadequacies are minimized with the use of the index Model or binary choice models (Greene, 2011). These are Logit and Probit models. Logit model assumes a logistic distribution while Probit assumes normal distributions. They have the same purpose of estimating dummy dependent variables. The Choice depends on the mathematical and statistical distribution convenience. This study applied Logit regression modeling.

Logit regression model, a discrete choice model which is used to draw inferences on the causal factors for firms linkage, the probability of participating in the integration of enterprises characteristics captured by the explanatory variables. It is expressed as:

$$
\begin{array}{r}
\mathrm{Y} i=\beta \chi i+u i---------(1) \\
\mathrm{Y} i=1 \text { If enterprises are linked and } 0 \text { otherwise }
\end{array}
$$

\subsection{Definition of Variables and Working Hypothesis}

\subsubsection{The Dependent variable of the model}

Dependent variable: Business linkage is the dependent variable of the model which shows the relationships and interactions between micro, small enterprises and large business. The dependent variable is show whether there is or not a linkage between the micro, small enterprise and large business. If there a linkage between them was denote by 1 and if not denote by 0 . Therefore, as stated above the model specification $\mathrm{Y}$ is the dependent variable of the model.

\subsubsection{Definitions of explanatory variables}

Independent variables: The independent variables $(\mathrm{Xi})$ represent factors that determine the business linkage of micro, small enterprises and large business. The independent variables that are assumed to influence the business linkage in the study area to determine the business linkage are stated as follow.

Sex of Enterprises Owners (SEX): This is dummy variable in the model, which takes a value 1 if the enterprises head is male and 0 if the enterprises head is female. Sex differentials in the enterprises play a significant role in business linkage performance in textile sub-sector.

Education: Education Level of enterprise's owner has positive significant effect on creating business linkage. When owner's education levels increase have anability to create linkage.

Family: The number of family enterprise's owner increase would have negative significant effect on creating business linkage.

Employee: The number of employees increase within enterprises would have a positive significant effect on creating business linkage between MSEs and large enterprises. When increase by sharing their all sided knowledge, experience have an opportunity to create linkage with large enterprises.

Raw Material: Availability 'of raw material has created market linkage between MSEs and large enterprises.

Finance: Financial resource enables firms to fulfill the quantity requirements of large enterprises and hence would have a positive significant effect on creating business linkage with large enterprises.

Technology: possessing the technology used to manufacture goods or services required by large enterprise. Required by large enterprises is significant in creating business linkage.

Workspace: whether MSEs had obtained workspace from the government or no Getting workspace has positive significant effect on creating business linkage.

Training: MSEs who obtained better training would have better linkage with large enterprises.

Information: Availability of information about market and large enterprises' requirements, working procedures has a positive significant effect on creating business linkage with large enterprises.

Experience(age): The business work experience was the number of years after establishment of enterprises has positive significant effect on creating business linkage between MSEs and large enterprises.

Leadership: Direct involvement and strong commitment of administrative leadership are a key in designing and implementing a linkage program are vital to the sustainability of a country's economic and MSEs development objectives.

Working capital: - Availability of working capital would have a positive significant effect on creating business linkage between MSEs and large enterprise.

Existence of Large Enterprises (LEUP): The researcher hypothesized that the presence of large enterprises has 
a positive significant effect on creating business linkage with micro, small enterprises.

Infrastructures (support): An accessing of more infrastructures such as electricity, water, telephone and road would have appositive significant effect on creating business linkage between MSEs and large enterprises.

Table 18: Description of dependent and independent variables used in the logit model

\begin{tabular}{|c|c|c|c|c|c|}
\hline Variable & $\begin{array}{c}\text { Variable } \\
\text { Label }\end{array}$ & Description & $\begin{array}{c}\text { Types } \\
\text { Variable }\end{array}$ & $\begin{array}{c}\text { Measurement } \\
\text { Values }\end{array}$ & $\begin{array}{l}\text { Exp. } \\
\text { Sign }\end{array}$ \\
\hline $\begin{array}{l}\text { Dep. } \\
\text { Variable }\end{array}$ & BusinessL. & Business linkage & Dummy & $1=$ Yes, $0=$ No & \\
\hline \multirow[t]{15}{*}{$\begin{array}{l}\text { Ind. } \\
\text { Variable }\end{array}$} & SEX & Sex of Enterprise's Head & Dummy & $\begin{array}{l}1=\text { male }, \\
0=\text { female }\end{array}$ & + \\
\hline & FAMILLY & Number of Families & Continuous & In numbers & - \\
\hline & EDU. & Education Level of Owners & Continuous & In grades & + \\
\hline & EMPLOYE & Number of Employee & Continuous & In numbers & + \\
\hline & WRKC & Working capital & Continuous & Amount of birr & + \\
\hline & TECH & Having required technology & Dummy & Yes $=1$, no $=0$ & + \\
\hline & FINANCE & Amount of capital & Continuous & Yes $=1$, no $=0$ & + \\
\hline & RAWM & Availability of raw Material & dummy & Yes $=1$, no $=0$ & + \\
\hline & INFO & Availability of information & Dummy & $\mathrm{Yes}=1, \mathrm{no}=0$ & + \\
\hline & EXP & Experience(age) of enterprises & Continuous & Number of years & + \\
\hline & TRAIN & Obtaining training this year & Dummy & Yes $=1$, no $=0$ & + \\
\hline & WSP & $\begin{array}{l}\begin{array}{l}\text { Workspace } \\
\text { government }\end{array} \\
\end{array}$ & Dummy & $\mathrm{Yes}=1, \mathrm{no}=0$ & + \\
\hline & LED & Leaders commitment & Dummy & $\mathrm{Yes}=1, \mathrm{no}=0$ & + \\
\hline & LEUP & Existing of large enterprises & Dummy & $\mathrm{Yes}=1, \mathrm{No}=0$ & + \\
\hline & INFRA & Infrastructures (support) & Continuous & $\begin{array}{l}\text { Access of water, } \\
\text { telephone, } \\
\text { electricity, road }\end{array}$ & + \\
\hline
\end{tabular}

\section{Source: Researcher table, 2017}

\subsection{PRE-TESTING}

Before the actual study, the researcher carried out, Pre-testing piloting was carried out on 28 members of MSEs who were not involved in the main study. Pre-testing was done to enhance consistency and dependency, accuracy and adequacy of the instruments. Consistencies of the test items were measured by the degree to which the test items attracted similar and related responses from the samples in the pilot testing exercise.

\section{Validity:}

Content validity was determined by pre-testing. This determined whether the items were correctly worded in order to avoid misinterpretation when they are finally administered to the samples in the main study. After pre-testing, the instruments were adjusted.

\section{Reliability}

The reliability was measured so as to find out the degree to which the measuring items gave similar results over a number of repeated trials. A test - retest method was be used to estimate the degree to which the same results could be obtained with a repeated measure of accuracy of the same concept in order to determine the reliability of the instrument.

\section{RESULT AND DISCUSSION}

\subsection{Descriptive statistics Results}

The descriptive analysis made use of tools such as mean, standard deviation, maximum, minimum and percentages. In addition, the Crosstab and chi-square statistics were employed to compare linked and non- linked enterprises with respect to some explanatory variables. Econometric analysis was carried out to identify the most important determinant factors that affect the business linkage and to measure the relative importance of significant explanatory variables on business linkage between MSE and large factory in textile sub-sector. The determinant factors such as Sex, Experience, Family size, Number of Employee, Education level, Raw material, Training, Technology, Finance; Existing of large enterprises, Working capital, Information, Workspace, Leadership style and infrastructure(supports) from government and stakeholders were examined using the logit model. 
Table 19: Socioeconomic characteristics of enterprises for continuous variables by linkage status

\begin{tabular}{|c|c|c|c|c|c|c|c|c|c|}
\hline $\begin{array}{c}\text { Variable } \\
\text { Name }\end{array}$ & & $\mathbf{N}$ & Mean & Std. Dev. & $\begin{array}{l}\text { Std. } \\
\text { Error }\end{array}$ & Min & Max & $\mathbf{F}$ & Sig. \\
\hline \multirow{3}{*}{$\begin{array}{l}\text { respondents } \\
\text { of sex }\end{array}$} & No & 43 & 0.67 & 0.474 & 0.072 & 0 & 1 & 0.329 & 0.568 \\
\hline & Yes & 28 & 0.61 & 0.497 & 0.094 & 0 & 1 & & \\
\hline & Total & 71 & 0.65 & 0.481 & 0.057 & 0 & 1 & & \\
\hline \multirow{3}{*}{$\begin{array}{l}\text { Education } \\
\text { in years of } \\
\text { schooling }\end{array}$} & No & 43 & 9.28 & 3.43 & 0.52 & 0 & 16 & 4.307 & $0.042 * *$ \\
\hline & Yes & 28 & 10.96 & 3.20 & 0.61 & 3 & 16 & & \\
\hline & Total & 71 & 9.94 & 3.42 & 0.41 & 0 & 16 & & \\
\hline \multirow{3}{*}{$\begin{array}{c}\text { Age of } \\
\text { enterprises } \\
\text { in yrs }\end{array}$} & No & 43 & 5.14 & 6.42 & 0.98 & 1 & 30 & 1.092 & 0.3 \\
\hline & Yes & 28 & 3.79 & 2.94 & 0.55 & 1 & 11 & & \\
\hline & Total & 71 & 4.61 & 5.34 & 0.63 & 1 & 30 & & \\
\hline \multirow{3}{*}{$\begin{array}{c}\text { family of } \\
\text { enterprises } \\
\text { owner }\end{array}$} & No & 43 & 4.60 & 3.22 & 0.49 & 1 & 18 & 0.153 & 0.697 \\
\hline & Yes & 28 & 4.89 & 2.73 & 0.52 & 2 & 14 & & \\
\hline & Total & 71 & 4.72 & 3.02 & 0.36 & 1 & 18 & & \\
\hline \multirow{3}{*}{$\begin{array}{c}\text { working } \\
\text { capital of } \\
\text { enterprises }\end{array}$} & No & 43 & 25953.0 & 64924.85 & 9900.95 & 0 & 380000 & 0.483 & 0.489 \\
\hline & Yes & 28 & 35589.0 & 42139.33 & 7963.59 & 0 & 125000 & & \\
\hline & Total & 71 & 29754.0 & 56890.74 & 6751.69 & 0 & 380000 & & \\
\hline \multirow{3}{*}{$\begin{array}{l}\text { employees } \\
\text { of } \\
\text { enterprises }\end{array}$} & No & 43 & 4.67 & 3.80 & 0.58 & 1 & 13 & 0.444 & 0.507 \\
\hline & Yes & 28 & 5.25 & 3.13 & 0.59 & 1 & 12 & & \\
\hline & Total & 71 & 4.90 & 3.54 & 0.42 & 1 & 13 & & \\
\hline
\end{tabular}

\section{** implies significant at $5 \%$ probability level}

Source: Own survey result (2017)

Education level of MSEs Owners:-

The survey results showed that the average educational status of enterprises was nearer to 10 years of schooling with the minimum and maximum grade of 0 and 16, respectively (Table 5). As figure 2 pi-charts indicated that the education levels of majority enterprises are grade 9-12.

This result indicated that those enterprises owners have more education level was created business linkage than which have less education level of enterprises owners. Moreover, the enterprises owner education level increases which enable them to create business linkage between MSEs and large enterprises. Those enterprises have an access to exposure to external environment, to acquaint with textile technologies, raw materials, to frequently meet large enterprises and to assure mutual benefit within business linkage and more aware of the importance of created business linkage between MSEs and large enterprises for making business profit This result allied with Tan,(2000), his finding implies that education has been linked to the entrepreneur's skills, motivation, self-confidence, problem-solving ability, commitment and discipline and enhance the individual's research and communication skills, foresight and imagination.

The average age of enterprises is nearer to 5 years with the minimum and maximum age of 1 and 30 respectively. Non-linked enterprises participated on average for higher number of years 5 as compared to the linked enterprises who participated on average for 3.78. The average years of non-linked enterprises are 5, whereas linked enterprises average age 3 years (Table5). This results indicated that year of establishment (age) enterprise was insignificant.

The family of enterprise's the average member of families nearly 5 with the minimum 1 and 18 maximum numbers of families. The non- linked enterprises number of families nearly the same 5 . So, the mean difference is stastically insignificant on creating business linkage. The average working capital of enterprises are birr 29754 with the minimum and maximum working capital 6751.89 and 380,000 respectively. The average working capital of non-linked enterprises are birr 25953, with the minimum and maximum working capital birr 0 and birr 380000 respectively. While the average working capital of linked enterprises are birr 35589 with birr 0 minimum and birr 125000 maximum working capital. This implies that linked enterprises have more working capital than non-linked enterprises. The mean difference of working capital between linked and non-linked enterprises are statically insignificant.

In general number of families, sex of owner's, employees and working capital on creating business linkage statistically insignificant.

\subsection{Results of Econometric Model}

\subsubsection{Estimation procedure of the econometric model}

This section presents the estimation procedure of econometric models of the logistic regression model of enterprises with and without linkages. As indicated earlier, the dependent variable in this model is a binary variable indicating whether the firms were linked or not. The model was estimated with STATA 12.0 computing software. 
In the estimation data from the two groups; namely, Linked and non-linked enterprises were pooled such that the dependent variable takes a value 1 if the enterprises was linked in the market and 0 otherwise. Variance inflation factor (VIF) was applied to test for the presence of strong multicollinearity problem among the explanatory variables. Before running the logit model to estimate propensity scores, the explanatory variables were checked for existence of sever multicollinearity problem different tests were undertaken.

A technique of Variance inflation factor (VIF) was calculated to detect the problem of multicollinearity among continuous explanatory variables. Accordingly, the VIF (Xi) result shows that the data had no serious problem of multicollinearity (Appendix 2). This is because, for all continuous explanatory variables, the values of VIF were by far less than 10 . Moreover, to avoid the problem of hetroscedasticity and normality, robust standard errors were employed.

\subsubsection{Determinants factors of Probability of being linked and non-linked enterprise}

The researcher had hypothesized fifteen explanatory variables while eight of them were statistically significant at less than $5 \%$ probability level. Those variable education level, availability of raw material, training, technology, finance; existing of related large enterprises, infrastructure and leadership style were significant, on the other hand Sex, age of enterprise, family, working capital, employee, information and workspace were found insignificant. (See table 15). The overall model specification was well fitted due to high value and statistical significant of chisquare and Pseudo R square. This implied that the hypothesis of at least one of the explanatory variable is different from zero is accepted.

Sex of Enterprises Owners (SEX): Sex differentials in the enterprises play a significant role in business linkage performance in textile sub-sector. More specifically, Sex differentials can be related to access to create business linkage and one may expect that male owners of enterprises are more exposure and experienced in create business and hence will be linked for they know more about the consequences of business linkage between MSEs and large enterprises in textile sub-sector. As the logit regression model result shows that being it is inversely insignificant. This implies that female owners tend to be relatively creating market linkage with large enterprises than male owners of enterprises.

Education Level of Enterprises Owner: The level of education in years of schooling was found directly affect and significant at less than $5 \%$ probability level. The result confirmed that if education increase by 1 year of schooling, the probability of linking enterprises to higher business would increase by $5.7 \%$. Moreover, when $\mathrm{x} 1=1$ the odds of $y=1$ increase by 1.37 infavor of linked enterprises. This implied that those who have higher level of education had better awareness, information, and ability to create linkage. This result is consistent with Seifu (2010).

Experience (age of the enterprise): Even though the researcher hypothesized that experience of enterprise would have positive significant effect on creating business linkage, the result of logistic regression model in table 15 shows that it is insignificant. Various researchers were claimed that age of enterprise has significant effect in creating business linkage (Endalkachew, 2008; UNCTAD, 2006). The claim of Ivarsson and Alvstam (2004) that stated the task of creating business linkage depends on the public sector seems valid in this case. Hence, the hypothesis that age of MSEs has significant effect on creating business linkage is rejected.

Amount of Working Capital: Those who have higher working capital were expected to have better awareness and ability to create linkage. However, amount of working capital was insignificant in this research. Hence, the arguments of various authors that claim financial capacity is determinant factor seem to be inconsistent with this finding.

Because most enterprises have an access to finance from different sources like world bank, credit finance from ACSI the collateral taken by city administration especially for those involved in manufacturing sector. In addition to this most enterprises members are not willing to take money by borrowing from financial institution with government collateral they are afraid religion impact and negative consequence after they borrowed. This implies that there is attitudinal problem of enterprises regarding to credit finance. This result aliened with reality of Kombolcha city Micro, small textile enterprises. There is no difference between enterprises those have working capital and have not both are di-linked.

Employees within Enterprises: The researcher hypothesized that the number of employees increase within enterprises would have a positive significant effect on creating business linkage between MSEs and large enterprises. But, the result of logistic regression model in table 15 shows that it is insignificant. Hence, the hypothesis that numbers of employees in micro, small enterprises increases have a positive significant effect on creating business linkage is rejected. 
Table 20: Econometric Results of determinants of Business Linkage in Textile enterprise

\begin{tabular}{|c|c|c|c|c|c|c|}
\hline Variable Name & Coef. & Robust Std. Err. & $\mathbf{Z}$ & $\mathbf{P}>\mathbf{Z}$ & Odds Ratio & Marginal Effect \\
\hline SEX & -1.095 & 0.953 & -1.150 & 0.250 & 0.334 & -0.213 \\
\hline EDUC & $0.314 * *$ & 0.137 & 2.290 & 0.022 & 1.369 & 0.057 \\
\hline AGEE & -0.168 & 0.151 & -1.110 & 0.267 & 0.846 & -0.030 \\
\hline FAMILY & -0.327 & 0.189 & -1.730 & 0.084 & 0.721 & -0.059 \\
\hline WRKC & 0.000 & 0.000 & -1.020 & 0.308 & 1.000 & 0.000 \\
\hline EMPLOYEES & 1.562 & 0.828 & 1.890 & 0.059 & 4.767 & 0.283 \\
\hline RAW & $1.972 * *$ & 0.875 & 2.260 & 0.024 & 7.188 & 0.357 \\
\hline FINANCE & $-1.280 * * *$ & 0.496 & -2.580 & 0.010 & 0.278 & -0.232 \\
\hline TECH & $1.435 * *$ & 0.698 & 2.060 & 0.040 & 4.199 & 0.260 \\
\hline INFO & 0.377 & 0.385 & 0.980 & 0.328 & 1.457 & 0.068 \\
\hline TRAIN & $-1.378 * *$ & 0.546 & -2.530 & 0.012 & 0.252 & -0.249 \\
\hline WS & 0.326 & 0.363 & 0.900 & 0.370 & 1.385 & 0.059 \\
\hline LEUP & $5.393 * * *$ & 2.078 & 2.600 & 0.009 & 219.940 & 0.794 \\
\hline LEADERS & $0.925 * * *$ & 0.349 & 2.650 & 0.008 & 2.523 & 0.167 \\
\hline INFRA & $1.002 * *$ & 0.492 & 2.040 & 0.042 & 2.724 & 0.181 \\
\hline cons & $-15.871 * * *$ & 5.576 & -2.850 & 0.004 & 0.0000001 & \\
\hline & $\begin{array}{r}\text { Logist } \\
\text { Wald ch } \\
\text { Log pseu }\end{array}$ & $\begin{array}{l}\text { ic regression } \\
\text { ii } 2(15)=\quad 31.78 \\
\text { ddolikelihood }=-24\end{array}$ & 92602 & $\begin{array}{r}\text { Number } \\
\text { Prob > } \\
\text { Pseudo }\end{array}$ & $\begin{array}{llr}\text { obs } & = & 7 \\
\mathrm{i} 2 & = & 0.00 \\
2 & = & 0.48\end{array}$ & \\
\hline
\end{tabular}

***and ** implies significant at $1 \%$ and $5 \%$ probability level

Source: Own Econometric Model result, 2017

Family of Enterprises owner: Even though the researcher hypothesized that the number of enterprise owner's family' increase would have negative significant effect on creating business linkage, the result of logistic regression model in table 15 shows that it is insignificant. Hence, the hypothesis that micro, small enterprise's owner's families have a negative significant effect on creating business linkage is rejected.

Having required technology: As shown in the table15,the regression model, having the required technology was found statically and directly significant at less than 5\%. That means, other things remained constant, those who possess the required technology would increase business linkage by $26 \%$ than others. This implied that those who have required technology had better ability to create business linkage with large enterprises. This is also in line with the descriptive statistics result as shown in Table 12. The researcher, Charles M., etal (2016), analyzed the influence of technology and technological attributes on formation of business linkages between MSEs and Large enterprises with majority of the respondents (42.7\%) agreed that technology was of great influence in formation of business linkages between MSEs and larger enterprises. The researcher further analyzed the influence of technology complexity, quality standards set by the large firms and cost of the technology as some of the technological attributes on formation of business linkages between MSEs and large enterprises and majority of the respondents agreed that those factors significantly influenced the formation of business linkages. Moreover, various researchers like (Sin, 2010; Jabbour and Mucchielli, 2007; GTZ, 2006; UNCTAD, 2006), have argued that technology was significant factor in creating business linkage.

Availability of Raw Material: Getting availability of raw material was found statistically and directly significant at less than 5\% probability level. The result confirmed that those enterprises that have availability of raw materials increase by one unit the probability of creating business linkage would increase by $35.7 \%$ with large enterprises. The result is significant and respondents also agree that availability of raw material is important factor in creating business linkage; the result of the logistic regression model is consistent with the result of the descriptive statistics. Various researchers have noted that lack of raw materials limits MSEs from creating business linkage with large enterprises (MoFED, 2012; Ihua, 2009).

Having information: As researcher hypothesized that the availability of information about market and large enterprise's requirement, working procedures has a positive significant effect on creating business linkage between MSEs and large enterprises. However, the above table 15 shows, that information have no significant effect in creating business linkage with large enterprises. Even if the positive sign is per the expectation of the researcher its effect was insignificant. It was expected that MSEs who have enough information about the large enterprises requirements and with whom to communicate would have better business linkage because large enterprises require knowing which enterprise can be qualified to supply products and create long lasting relationship While in the descriptive statistics in table 10, the result is significant and majority of respondents also believe that having the right information is important factor in creating business linkage, the result of the logistic regression model is inconsistent with the result of the descriptive statistics. Thus, the hypothesis that information is determinant factor 
in creating business linkage is rejected.

Lack of Training: According to the logistic regression result shown in Table 15, getting training is found to affect business linkage inversely related and it is significant at less than 5\% significance level. That means other things remained constant, Micro, small enterprises those have not get training dis favor business linkage with large enterprises by $24.9 \%$ less those of who have obtained training. This is consistent with the descriptive statistics in Table11, that the majority of respondents believe that training is important for business linkage. Various researchers claims that, UNCTAD, (2010), providing training to local MSEs and supporting training programmes; using foreign/ large firms as partners in technology upgrading programmes; Promoting supplier associations, making investment to develop managerial capability of MSEs are described as important measures to promote business linkage.

Enhancing capacity for fashion and design factories, Improving managerial and entrepreneurial capability.

Shortage of Finance: While in regression model shortage of finance was found statistically and inversely affect business linkage at $1 \%$ probability level of significance. This implies that shortage of finance of micro, small enterprises increase by one unit the probability of linking with large enterprises decrease by $23.2 \%$. Hence, Kinyua,(2014) state that claim financial capacity is determinant factor seem consistent with this. The study results also indicated that as number of years in operations increased the performance increased. Since finance rather than working capital shows the current financial strength of MSEs, it is possible to claim that financial capacity is a determinant factor in creating business linkage. Financial resource enables firms to fulfill the quantity requirements of large enterprises and hence would have better business linkage with large enterprises. Therefore, the hypothesis that finance is a determinant factor in creating business linkage is accepted.

Working space (proxy): The results from the logistic regression model showed that work space does not have a significant effect on business linkage between MSEs and large enterprises. Thus, hypothesis that getting workspace (proxy) is significant in creating business linkage is rejected.

Leadership Style: The logistic model implies that, leadership has statistically and directly significant at less than $1 \%$ probability level. The result confirmed that the availability of more committed and capable leaders at all levels would enhance linkage between MSEs and large enterprises by $16.7 \%$. This is consistent with the descriptive statistics in table 15 that the majority of respondents believe that getting the right support form capable and committed leaders from zone to Keble levels very important to create business linkage between MSEs and large enterprises in textile sub-sector significant at $1 \%$ probability level (Table15).

Infrastructure: According to regression model result enterprises accessing infrastructure was found statistically and directly significant at less than 5\% probability level. This means an accessing of more infrastructures such as electricity, water, telephone and road would increase business linkage between MSEs and large enterprises by $18.1 \%$. This implies that enterprises those who have accessed infrastructure had better working environment, market opportunities, easily addressed customers and motivation to create business linkage with large enterprises. Existence of Large Enterprises (LEUP): The researcher hypothesized that the presence of large enterprises has a positive significant effect on creating business linkage with micro, small enterprises. When large enterprises consume MSE's product as an input, then mutual benefit would be created within enterprises. As logistic regression model implies that large enterprises use as an input micro, small enterprise's product was found statistically and have a positive significant effect in creating business linkage at less than $1 \%$ probability levels. The result confirmed that if large enterprises uses MSE's product continuously would increase market linkage between enterprises by $79.4 \%$. Moreover, when micro, small enterprise's output increasingly used by large enterprises $(\mathrm{x}=1)$ the odds of $\mathrm{y}=1$ increased by 219.9. This indicates that MSE's output used as an input for large enterprises have assured mutual benefit and market linkage between micro, small and large enterprises in textile sub-sector. Researcher claims that, Habtamu T., (2016), the existences of related and supportive sectors have also significant effect on creating business linkage. This implies that expanding and attracting related and supportive sectors. 
Table 21: Summary of Hypothesis Tests

\begin{tabular}{|c|c|c|c|c|c|}
\hline & Hypothesis & $\begin{array}{l}\text { Expected } \\
\text { sign }\end{array}$ & $\begin{array}{c}\text { Actual } \\
\text { sign }\end{array}$ & $\begin{array}{c}\text { Level of } \\
\text { significance }\end{array}$ & Decision \\
\hline 1 & $\begin{array}{l}\text { Education level of MSEs owners has a positive } \\
\text { significant effect on creating business linkage. }\end{array}$ & + & + & $\begin{array}{l}\text { Significant at } \\
5 \%\end{array}$ & Accept \\
\hline 2 & $\begin{array}{l}\text { Availability of raw material has created business } \\
\text { linkage between SMEs and large enterprises. }\end{array}$ & + & + & $\begin{array}{c}\text { Significant at } \\
1 \%\end{array}$ & Accept \\
\hline 3 & $\begin{array}{l}\text { Age of enterprises (business work experience) has a } \\
\text { positive significant effect on business linkage. }\end{array}$ & + & - & Insignificant & \\
\hline 4 & $\begin{array}{l}\text { Availability of working capital would have a positive } \\
\text { impact on business linkage. }\end{array}$ & + & - & Insignificant & \\
\hline 5 & $\begin{array}{l}\text { Availability of technology required by large enterprises } \\
\text { is significant effect in creating business linkage. }\end{array}$ & + & + & $\begin{array}{c}\text { Significant at } \\
1 \%\end{array}$ & Accept \\
\hline 6 & $\begin{array}{l}\text { Availability of adequate information has positive } \\
\text { significant effect on creating business linkage between } \\
\text { MSEs and large enterprises. }\end{array}$ & + & + & Insignificant & \\
\hline 7 & $\begin{array}{l}\text { Leader's commitment and capability has a significant } \\
\text { effect on linking MSEs with large enterprises. }\end{array}$ & + & + & $\begin{array}{c}\text { Significant at } \\
1 \%\end{array}$ & Accept \\
\hline 8 & $\begin{array}{l}\text { MSEs who obtained better training would have better } \\
\text { linkage with large enterprises. }\end{array}$ & + & + & $\begin{array}{l}\text { Significant at } \\
5 \%\end{array}$ & Accept \\
\hline \multirow[t]{6}{*}{9} & $\begin{array}{l}\text { Getting workspace has significant positive effect on } \\
\text { creating business linkage }\end{array}$ & + & - & Insignificant & \\
\hline & $\begin{array}{l}\text { Sex differentials in the enterprises owner may have } \\
\text { positive /negative effect. }\end{array}$ & $+/-$ & & Insignificant & \\
\hline & $\begin{array}{l}\text { The number of family increase would have negatively } \\
\text { affected creating business linkage. }\end{array}$ & - & - & Insignificant & \\
\hline & $\begin{array}{l}\text { Finance has a positive significant effect on creating } \\
\text { business linkage with large enterprises. }\end{array}$ & + & + & $\begin{array}{c}\text { Significant at } \\
1 \%\end{array}$ & Accept \\
\hline & $\begin{array}{l}\text { The number of employees increase within enterprises } \\
\text { would have a positive significant effect }\end{array}$ & + & + & Insignificant & \\
\hline & $\begin{array}{l}\text { The presence of large related enterprises has a positive } \\
\text { significant effect. }\end{array}$ & + & + & $\begin{array}{c}\text { Significant at } \\
1 \%\end{array}$ & Accept \\
\hline
\end{tabular}

Source: Own survey result, 2017

\section{SUMMARY, CONCLUSIONS AND RECOMMENDATION}

In this chapter, the major findings are summarized; conclusions are drawn based on the findings and recommendations are forwarded for the concerned bodies.

\subsection{Summary}

According to Federal Micro and Small Enterprise development agency,(2011), the Ethiopian economy, although still highly dominated by the Agricultural Sector in terms employment (80\%), its contribution to the GDP (44\%) and its share in the export market $(80 \%)$, is witnessing one of the fastest growing economies in Africa as well as in the world.

The study was identified the determinant factors that affect business linkage between MSEs and large enterprises in kombolcha city. It was also tried to address the opportunity, supports and challenges they acquire from government and kombolcha textile Share Company. All of 71 MSEs those are engaged in textile sub-sector were taken for the study using census. In the process of answering the basic questions, a questionnaire that include general information, opportunity and challenges of enterprises in creating business linkage, support from government and kombolcha textile share company and determinant factors of the enterprises was designed in a closed ended, open ended, dichotomous and likert scales. Moreover, structured interviews were held with top officials of Kombolcha technique vocational and enterprises development office head, Textile share company manager, Polytechnic college dean, Micro finances manager and 5 Keble's MSEs one shop centers representatives and south wollo zone TVED office representative. After the data has been collected, it was analyzed using version 20 SPSS for the descriptive statistics (frequency and percentage) and the result of determinant factors in creating business linkage between MSEs and large enterprises was analyzed using logit regression models. Based on 71 enterprises owner respondents and interview results acquired from the concerned officials, the major findings of this study are summarized as follows:

* Most of the enterprises business work experience (age of enterprises) are under the age category of 1-5 
years $(66.2 \%)$ and 9 th- 12 th grade $(45.1 \%)$.

* Majority of the respondents (78.9\%) have a family size of from 1-5 and about, $14.1 \%$ of enterprises have from 6-10 family size. The only the remaining 7\% respondents that their family size is greater than 10 .

* Majority of the respondents (63.4\%) hire less than 5 employees in their enterprise. Whereas $22.5 \%$ respond that they employ from 6-10 workers in their enterprises. Moreover $11.3 \%$ and $2.8 \%$ of the respondents hire from 11-15 employees and greater than 15 employees respectively.

* The Majority of $95.4 \%$ MSEs in kombolcha city were not supplied their product to any of the large enterprises , only about $5.6 \%$ of the investigated MSEs had sold their products to large enterprise

* About $95.8 \%$ MSEs in the city had not an opportunity which helps to integrate with large business.

* Majority of the respondents $61(81 \%)$ believe that raw material shortage is one the challenges in their course of activity and in creating business linkage.

* Majority of the enterprises $(80.2 \%)$ agreed that shortage of finance particularly working capital was their main constraint in their work and in creating business linkage with large enterprises.

* Majority of $87.3 \%$ of respondents claimed that there were no organizations that can provide information of large enterprises.

$\$ 71.9 \%$ of the enterprises believed that lack of proper training is a reason why they failed to create business linkage. About $90.1 \%$ and $80.3 \%$ respectively they replied as agreed that lack of technical skills and managerial skills had adversely affected them in creating business linkage.

\& About $74.6 \%$ of the enterprises replied they had sheds. However, $90.1 \%$ of MSEs investigated responded inappropriate proxy of workspace is a basic challenge in creating business linkage.

* Majority of the respondents $83.1 \%$ agreed that lack of technology has a great influence in formation of business linkages between MSEs and larger enterprises.

\& More than half of the respondents 53.5\% replied that they are not getting any support from the company to create business linkage.

* The regression model, having the required technology is significant at $5 \%$ level of significance. That means, other things remained constant, those who possess the required technology are 2.87 times more likely to create linkage than otherwise.

* Getting availability of raw material has significant effect in creating business linkage with large enterprises. MSEs who had better availability of raw materials were 4.88 times more likely to create linkage than others.

* Getting training is found to affect business linkage inversely at $5 \%$ of significance level. That means other things remained constant, MSEs who have don't have training are 3.266 times less likely to have business linkage than those of who have obtained training

* From the logistic model leadership has significant effect on business linkage. That means the availability of more committed and capable leaders at all levels will enhance linkage of MSEs with large enterprises.

* As logistic regration model shows that information, age of experience, workspace and working capital has no significant effect in creating business linkage with large enterprises.

\subsection{Conclusions}

The econometric model and descriptive statistics result showed that Lack of raw materials is the most serious problem of MSEs and this problem can be addressed by creating business linkage. However, the existing vertical linkage in Kombolcha City is very limited and the issue of getting access to raw materials is the top agenda of MSEs. Factors such as education level, finance, training technological capability, and infrastructure, capable and committed leaders are determinant factors in creating business linkage. However, majority of MSEs investigated were in a weak position with respect to such factors and as a result the existing business linkage in the City was limited. Improving educational levels of MSEs owners, enhancing technological transformation to strengthen business linkage. MSEs have financial constraint to supply the quantities required by large enterprise which become significant constraint in creating vertical linkage. The problem was aggravated by the lack of easy access to credit due to collateral requirement and other bureaucracies of lending institutions. MSEs have a significant technical and managerial skill gaps that need to be solved through training; however, the trainings provided in the City by kombolcha polytechnic were limited.

Due to the presence of lack of required technology of textile micro and small enterprises in the City and hence failed to supply their product to large enterprises. In adequate infrastructure implementation such as road, water, telephone and electricity were the other problem which contributed to the low level of business linkage.

On the other hand the expanding and attracting related large sectors not adequately implemented and loose operational day to day follow up and support problems have a significant effect for limited business linkage between MSEs and large enterprises in textile sub-sector. This problem seems the result of inadequacy of government support and low involvement to establish appropriate motivational and enforcement mechanisms to link local MSEs with large/ FDI. 


\subsection{Recommendations}

Based on the findings, the researcher has made the following recommendations that can help in creating business linkage:

$\checkmark$ The study revealed that education level of entrepreneurs statistically positively and significantly influenced business linkage. This clearly indicates that for effective utilization of resources, improved technologies, enhancing the level and quality of educational status of entrepreneurs is a key step.

$\checkmark$ Accessing of raw materials and finance are very essential in order to achieve sustainable business linkage between MSEs and large enterprises in textile sub-sector. Since lack of raw material is one of the main constraints that MSEs faced and creating business linkage helps to solve this constraint through indigenous raw materials. Financial lending institutions and the government need to avail funding of MSEs based on soundness of project worthiness.

$\checkmark$ Moreover, the government needs to continuously up grading the skills of MSEs, rather than focusing only newly established MSEs, take additional measures to increase the number of supportive and related large enterprises, to local MSEs in terms of market and technology transfer. The expansion of MSEs training center should be given due attention. Technical and vocational training centre in Kombolcha needs to better integrate with MSEs and large enterprises, private sectors so as to enhance its capacity.

$\checkmark$ To solve the market problem of MSEs, it is better to develop mutual benefit mechanisms that motivate large enterprises to link with MSEs.

$\checkmark \quad$ The Amhara regional government should establish appropriate governed rule, motivational and enforcement mechanisms to link local MSEs with large enterprises. Moreover, the government focused on creating market linkage to MSEs with large enterprises particularly in textile sub-sector.

$\checkmark \quad$ The industrial zone development plan was designed and being implemented by federal government to avail infrastructural facilities. Infrastructures are built in order to create market linkages in Kombolcha City to pay attention to the improvement of institutional coordination and accessing roads, electricity, pure water and telecommunication.

$\checkmark$ Government giving attention to build capable and committed leaders especially at operational levels who have an ability and trust to implement strong follow up and support mechanism, to change attitudinal dependency problems of MSE's owners and to make them competent for their sustainable business linkage. To assure mutual benefit between small and large enterprises and technological transformation to strengthen business linkage is fundamental.

\subsection{Recommendation for further study}

The study was limited to assess the impact of being industry cluster in the formation of successful business linkages between MSEs and larges firms. A study on the nature of linkages between MSEs and large firms and their contributions and benefits to the growth of MSEs and local economy will also bring more light to this field. There is also a need to explore the influence of skills acquired in the foreign investments on formation of business linkages.

\section{REFERENCES}

Charles M., etal ( 2016) 'Factors Influencing The Establishment of Successful Business Linkage Between Micro and Small Enterprises and large enterprises in Kenya': Vol. 3,Iss. 4 (73), pp 1361-1375, Nov 9, 2016, www.strategicjournals.com.

Ferede, T., SKebede, K. and Tarfasa, S. (2015), Economic growth and employment patterns,

dominant sector, and firm profiles in Ethiopia: Opportunities, challenges and Prospects,R4D Working Paper $2015 / 2$

Biru Ashenafi, G.(2014).The Impact of Subsidy on the Growth of Small and Medium Enterprises (SMEs) :Journal of Economics and Sustainable Development www.iiste.org ISSN 2222-1700 (Paper) ISSN 2222-2855 (Online) Vol.5, No.3, 2014, 178.

Berihu A., Abebaw Z., and Biruk T. (2014) indentifying key success factors and constraints in Ethiopia's MSEs development: An exploratory research. Ethiopian Development Research Institute Addis Ababa, Ethiopia ,October, 2014.

Kinyua, N., (2014 ).Factors Affecting the Performance of Small and Medium enterprises in the Jua Kali Sector In Nakuru Town, Kenya: -ISSN: 2278-487X, p-ISSN: 2319-7668. Volume 16, Issue 1. Ver. IV (Jan. 2014), PP 80-93 www.iosrjournals.orge www.iosrjournals.org 80 | Page

Paluku KAZIMOTO, (2014).Assessment of Challenges facing Small and medium Enterprises towards International Marketing Standards: a Case Study of Arusha Region Tanzania, vol.4,No.2,April, 2014, pp.303311.

UCTAD(2010) Creating Business Linkages: a Policy Perspective. New York and Geneva Sin, K.C.(2010) 'The Success Stories of Malaysian SMEs in Promoting and Penetrating Global Markets Through Business 
Competitiveness Strategies.'

African Development Bank (2000) 'Linkages between SMEs and Large Industries for Increased Markets and Trade: an African Perspective.' Abidjan, Economic Research Papers (53) Available at: http://www.afdb.org/fileadmin/Documents /Publications (Accessed: 15 april 2017)

Carlos, A., Fausto, R. (2013). Business Linkage: innovation in the value chain.

Botelho, D. and Bourguignon, M. F.( 2011) 'Fostering Linkages between Transnational Corporations and Small to Medium-Sized Enterprises in Brazil.' BAR, Curitiba, 8(3), pp. 247-265 Business dictionary retrieved from: Businessdictionary.com /definition/linkages.html (accessed: 20 april.2017)

Jeng-Min Wong, (2011), a relational view of resources-based theory: the case of internationalization of Li \& Fung Group. Department of International Trade and Logistics, Overseas Chinese University, Taiwan. The Journal of Human Resource and Adult Learning Vol. 7, Num. 2, December 2011.

Centre For Urban Future (2010) 'Breaking in to Corporate Supply Chain 'Available at: http://www.nycfuture.org/imagesf(Accessed: 10 Dec.2017).

Chen, T. et al. (2004) 'Foreign direct investment and local linkages.' Journal of International Business Studies, 35, pp.320-333.

Endalkachew, M. (2008) 'Underlying Causes of Micro and Small Business Failures in Addis Ketema Sub City: A Case Study.' Addis Ababa University,'Available at: http://etd.aau.edu.et/dspace/bitstrem(Accessed: 15 Dec.2017).

Adugnaw,M.(2013) The effecet of socio economic factor small enterprise, Mekelle .Ethiopia

Berry, A. (1997) 'SME Competitiveness: The Power of Networking and Subcontracting. Washington,D.C.No.IFM-105Available at:http://www. microfinanzas.orgc/uploads/media(Accessed: 11 Nov.2017)

CACCI (2003) 'Recommendations on SME Development for Submission to the APEC Ethiopian Central Statistical agency (2013)'Available at: www.citypopulation.de/Ethiopia. (Accessed: 8June, 2017)

Field, M. and Knopp, D.(2002) ' Business Linkages and Producer Groups in Bangladesh: options for rural microenterprise development.’ USAID, Available http://mlkdid.zaloni.net/sites/microlinksbusiness.(Accessed: 2 Juna., 2017.

Giroud, A. (2006). Is Government support really worth it? Developing Backward Linkages in Malaysia. In A. Tavares \& A. C. T Aurora (Eds).'Multinationals, clusters and innovation: does public policy matter? , PP. $111-154$

Giroud, A. (2007). MNEs vertical linkages: the experience of Vietnam after Malaysia. International Business Review, 16(2), 159-176.

European Commission (2005) 'The New SME Definition: User guide and model declaration.' Enterprise and Industry Publications. Available at: http://ec.europa.eu/enterprise/policies/sme(Accessed: 10 Apr.2017)

Ihua, U.B.(2009) 'SMEs Key Failure-Factors: A Comparison between the United Kingdom and Nigeria.' KamlaRaj 2009 J SocSci, 18(3), pp.199-207.

Jenkins, B. et al. (2007) 'Business linkages: lessons, opportunities and challenges. Cambridge: Harvard University Press. Available at: http://www.hks.harvard.edu/m-rcbg/publications/report(Accessed: 20 April,2017)

Kumar, R. S., and Subrahmanya, B. (2007). 'Subcontracting relationships of Indian SMEs with global TNCs. Do SMEs gain? How?' Journal of Asian economics, 5 (39) .

Kozo, K. et al (2005) 'Reconsidering the Backward Vertical Linkage of Foreign Affiliates: Evidence from Japanese Multinationals' RIETI Discussion Paper Series 05-E-019, pp. 1-35 Knopp , D. 2002 'Business Linkages and Producer Associations in Bangladesh - Options for.

Aldaba, R.M(2008) 'SMEs in the Philippine Manufacturing Industry and Globalization: Meeting the Development Challenges.' Discussion Paper Series. No. 2008-15.Availableat: http://saber.eaber.org/sites/default/files/documents (Accessed: 15Nov.2017) Amhara Region State MSEs development strategy (2011), Bahir Dar; Ethiopia Business Advisory Council (ABAC).'Available at: http://www.cacci.org.tw/Journal (Accessed: 10 Dec.2017)

Dunning, J. H. and Lundan, S. (2008). 'Institutions and the OLI paradigm of the multinational enterprise.' Asia Pacific Journal of Management, 25(4), pp. 573-593.62

Dyer, J.H. and Singh, H. (1998) 'the Relational View: Cooperative Strategy and Sources of International Competitive Advantage.' The Academy of Management Review, 23(4),pp. 660-679.

Federal MSEs development agency report (2013), Addis Abeba, Ethiopia http://www.ena.gov.et/story.( Accessed at: $10 \mathrm{Feb}, 2017)$.

Governement of India (2010) Report of Prime Minister's Task Force on Micro, Small and Medium Enterprises. India. Available at: http://www.dcmsme.gov. (Accessed:15 Dec.2017).

GTZ, (2006) 'Promoting Business Linkages: Overview and Tool.' Deutsche Gesellschaftfür Technische Zusammenarbeit.

Ivarsson, I. \&Alvstam, C. G. (2004) 'International technology transfer through local business linkages: the Case 
of Volvo Trucks and Their Domestic Suppliers in India.' Oxford Development Studies, 32(2), pp.241-260.

Jabbour, L.and Mucchielli, J.L.( 2007) 'Technology Transfer Through Vertical Linkages: the Case of the Spanish Manufacturing Industry.' Journal of Applied Economics,10(1), pp. 115136. Rural ME Development.' Available at: http://pdf.usaid.gov/pdf (accessed:12 Dec2017).

APEC,PERU (2016). Promoting SMEs' Integration into Global Value Chains in Major Industries Comprehensive Policy Report. November 14-15, 2016 Lima, Peru, Concluding Senior Officials’ Meeting.

Lemlem, M. (2013) 'MSEs are the Inceptions of Tomorrow's Large Enterprises.'

Matee, M. and Anastasov, Y. (2010) 'Determinants of Small and Medium Sized Fast Growing Enterprises in Central and Eastern Europe: a panel data analysis.' Financial Theory and Practice 34 (3) 269-295.

Mead, D.C. (1998) 'Small Enterprise Growth through Business Linkages in South Africa.African Economic Policy Paper.' Discussion Paper, (26), pp.1-14 Available at: http://pdf.usaid.gov/pdf_docs/pnacg(Accessed: 25 Oct.2017)

Carluccio, J. \& Fally, T., 2012. "Foreign Entry and Spillovers with Technological Incompatibilities in the Supply Chain.. Journal of International Economics,"Working papers 410, Banque de France.

Asma, B. Diabate A., Othman, A.(2015) Establishing the Factors Affecting the Growth of Small and Mediumsized Enterprises in Algeria

Elliot, J. (2005) Using Narrative in Social Research: Qualitative and Quantitative approaches. London Sage American International Journal of Social Science Vol. 4, No. 2; April 2015

MoFED(2012) 'Federal Democratic Republic of Ethiopia Growth and Transformation Plan (2010/11-2014/15) Annual Progress Report for F.Y. 2010/11.' Addis Ababa,

Ethiopia. Retrieved from: http://www.mofed.gov.et (Accessed: 20 Oct , 2017)

Nganga, S.I et al. (2011) 'Determinants of SMEs growth (wood enterprises): Infrastructure,

Technology and Collective Efficiency.' Journal of Geography and Regional Planning, 4(8), pp. 498-504.64.

Ntshona, S. (2012) 'Business Linkages as a Strategy for Marginalized Manufacturing Industries in Township of Gwera Zimbabwe.’ Retrieved from: http://www.uj.ac.za/EN/Faculties(Accessed: 15 Jan. 2017).

Obadan, M. I. and Agba , A.V. (n.d) 'Small and Medium Enterprises Development Policy in Brazil, Malaysia, South Africa and South Korea: Lessons For Africa And Nigeria.

Okatch, A. and Mukulu, E. (2011a) 'Constraints to Subcontracting Arrangements between SMEs and Large Firms in the Motor Vehicle Industry in Kenya.’ International Journal of Business and Social Science, 2(15), pp.208223.

Okatch, A. and Mukulu, E.( 2011b) 'the Motivation Behind Subcontracting Relationships between Large Firms and SMEs In The Motor Vehicle Manufacturing Industry In Kenya.' Australian Journal of Business and Management Research, 1(3), pp. 25-38

OECD (2009) 'The impact of the global crisis on SME and entrepreneurship financing and policy responses.' Paris: Centre for Entrepreneurship, SMEs and Local Development: OECD. Retrieved from :http://www.oecd.org/industry (Accessed: 12 Feb. 2017.

Oni, E.O and Daniya A.A (2012) 'Development of Small and Medium Scale Enterprises: The role of Government and other Financial Institutions.' Arabian Journal of Business and Management Review,1(7), pp.16-29

Pathak, R.R. (2013) 'Sample size: from formulae to concepts - II.' International Journal of Basic \& Clinical Pharmacology, 2(1) pp.94-95 2(1)

Prahalad, C.K and Hamel, G. (1990) ‘the Core Competence of the Corporation.' Harvard Business Review, p.7990

Regnier, P.(2006) 'Japanese Small Enterprise Development Cooperation Overseas: Linkages With Japan's Industrial Organization and Ties With Japanese SMEs.' Graduate Institute of Development Studies, Geneva, Switzerland, pp.1-42. Retrieved from: http:/www.jil.go.jp/profile/documents/Regnier (Accessed: 14Nov.2015)

Ritala, P. and Ellonen, H. (2010) 'Competitive Advantage in Inter-Firm Cooperation - Old and New Explanations.' Journal of Competitiveness Review 29(5), pp. 367-383.

Rudawska, I. (2010) 'Interconnected Firms' Relationships as a Source of Competitive Advantage .BEH - Business and Economic Horizons, 2(2), pp. 7-16.65

Jodie K., Dirk W.,(2008):The role of textile and clothing industries in growth and development strategies. Investment and Growth Programme Overseas Development Institute ,7 May 2008.

Scott, J. (2007)' Foreign Direct Investment and Local Linkages: an Empirical Investigation.' Management International Review, 47(1), pp.1-27. Sin, K.C.(2010).

Ndemo,B.E \& Smallbone, D. (2015) Linkage Dynamics between Small and Large firms in Kenya, DBA Africa Management Review, 5(1). 38-59.

UNCTAD 2010. Creating Business Linkages: A Policy Perspective. United Nations, New York.

Sin, K.C.(2010) 'The Success Stories of Malaysian SMEs in Promoting and Penetrating Global Markets Through Business Competitiveness Strategies.' Asia CBS, Copenhagen Discussion Papers 2010 - 3315 Research 
Centre, Retrieved from: http://openarchive.cbs.dk/bitstream/handle (Accessed: 25 Feb, 2017).

Shen, X. (2008).Linking local suppliers to multinationals: how can governments play a useful role? Washington: World Bank. Bureau, U. c. (2002). Economic census webpage U.S.A.

Katie Clancy, Sasha Parameswaran,Mark Thomas, (2014): Making Market Linkages. Nathan Associates London Ltd, September 2014.

Hassink, R. (1997). Localized industrial learning and innovation policies. European Planning Studies 5 (3): 279 82.

Tambunan, T. (2006) 'Micro, Small and Medium Enterprises and Economic Growth.' Working Paper Series (14) Retrieved from http://103.28.161.15/pusatstudi_industri/PUSAT (Accessed: 20 Nov. 2017)

Tsai, W. and Ghoshal, S. (1998) 'Social Capital and Value Creation: the Role of Intra-firm Networks', Academy of Management Journal 41(4), pp.464-476.

UCTAD (2006) Deepening Development through Business Linkages. United Nations, NewYork and Geneva,

UNDO (2003) 'Promoting Business Linkages in the Automotive Component Sector of India: A Case Study Presented at the Annual Global Learning Forum of the UN Global

Compact.' Belo Horizonte, Brazil Retrieved from http://www.globalcad.org/cadoteca/ informe (Accessed: 28 Dec, 2017)

USAID (2008) 'The Role of Micro, Small, and Medium Enterprises in Economic Growth: a Cross-Country Regression Analysis.' Micro report, 135 Retrieved from: http://pdf.usaid.gov/pdf_docs/PNADO560 (Accessed: 2 Feb.2017)

Chemweno P, Githaiga J, Njuguna D, Odhiambo S., (2014), promoting sustainable small and medium textile manufacturing enterprises in Kenya: Department of Manufacturing, Industrial \& Textile Engineering, School of Engineering, Zimbabwe Journal of Science \& Technology Special Issue (2011) MS. 31 Published 2014.

Belay, k., Asmera, T., Tekalign, M. , (2015), International Journal of Scientific and Research Publications, Volume 5, Issue 1, January 201510 ISSN 2250-3153 www.ijsrp.org.

M. Nureldin Hussain,(2000)Linkages between SMEs and Large Industries for Increased Markets and Trade: An African Perspective. African Development Bank, Strategic Planning and Research Department. Economic Research Papers.

Wong, J. (2011) 'A Relational View of Resources-based Theory: The Case of Internationalization of Li \& Fung Group.' The Journal of Human Resource and Adult. UNCTD, (2010). Creating Business Linkages: A Policy Perspective. New York and Geneva, 2010.

UGANDA COUNTRY REPORT,( 2014), Eastern Africa's Manufacturing Sector Promoting Technology, Innovation, Productivity And Linkages: Uganda Country Report, November 2014.

Federal Micro and Small Enterprises Development Agency (2011), FEMSEDA Annual Report 2011.

Paluku Kazimoto,(2014),assesment of challenges facing Small and Medium Enterprises towards International Marketing Standards: a Case Study of Arusha Region Tanzania: International Journal of Academic Research in Accounting, Finance and Management Science, Vol.4, No.2,April 2014, pp.303-311

AACCSA,(2015) an overview of Ethiopian manufacturing sector. Addis Ababa chamber of commerce and sectoral association: October, 2015, Addis Ababa, Ethiopia. Aimee Hampel-Milagrosa and Caroline Reeg,(2016): Micro, small and medium enterprises as drivers for job creation and decent work. "Employment and decent work for poverty eradication in support $f$ the second UN Decade forthe Eradication of Poverty (20082017).UN Conference Centre, Bangkok 4-6 May 2016

Musundi, A. S \& Ogollah, K. (2014). Challenges facing business linkages between small and medium enterprises and mobile telephone companies in kenya. European Journal of Business Management, 1 (11), 298-318.

Kithuku, M., Gichira, R. (2016), factors influencing the establishment of successful business linkage between micro and small enterprises and large enterprises in kenya. Vol. 3, Iss. 4 (73), pp 1361-1375, Nov 9, 2016, Ministry of Finance and Economic Development (MOFED), Growth and Transformation Plan (GTP) Annual Progress Report for F.Y 2012/2013, Addis Ababa, February 2014.Ministry of Finance and Economic Development (MOFED),

Growth and Transformation Plan (2010/2011-2014/2015), Volume II, Policy Matrix, Addis Ababa, December 2010. Firew, M., (2014), Networking And Business Performance Of Medium Sized Enterprises :In Addis Ababa.

OECD (2005), Oslo Manual 3rd edition: Guidelines for collecting and interpreting innovation data.

UNCTAD (2004). World Investment Report 2004: The Shift Towards Services .New York/Geneva.

Federal Democratic Republic of Ethiopia (FDRE) (2011), Micro and small enterprises development, support scheme, and implementation strategies. Addis Ababa, Ethiopia.

UNCTAD 2010. Creating Business Linkages: A Policy Perspective. United Nations, New York.

World Bank, (2004). Microfinance and Poverty Eradication: Strengthening Africa's Microfinance Institutions (New York, United Nations,)

Jenkins B., Akhalkasi A., Roberts B. \& Gardiner A. (2007) Business linkages; Lessons Opportunities and 
challenges. IFC International Business Leaders Forum and the Kennedy School of Government, Harvard University.

ILO. (2007). Small Change, Big Changes: Women and Microfinance. Geneva, Switzerland: International Labour Organization.

Reeg, C. (2013b). Micro, small and medium enterprise upgrading in India - Learning from success cases (Studies 78). Bonn: German Development Institute /Deutsches Institut for Entwicklungspolitik.

International Labour Organization. (2014b). World social protection report 2014/15: Building economic recovery, inclusive development and social justice. Geneva: Author, International Labor Office.

Gindling, T. H., \& Newhouse, D. (2014). Self-employment in the developing world. World Development, 56, 313331.

De Kok, J., Deijl, C., \& Veldhuis-Van Essen, C. (2013). Is small still beautiful? Literature review of recent empirical evidence on the contribution of SMEs to employment creation.

Granovetter, M.S. (1982). The strength of weak ties: A network theory revisited. In: Marsden PV, Nan Lin. editors. Social Structure and Network Analysis. Beverly Hills, Calif, Sage, 201-233.

De Mel, S., McKenzie, D., \& Woodruff, C. (2008). Who are the microenterprise owners?Evidence from Sri Lanka (Discussion Paper 3511). Bonn: Institute for the Study of Labor.

Tan,W. (2001). Practical research methods: With applications in building and real estate, Prentice Hall, Singapore.

Ethiopian Ministry of Industry, (2013). Ethiopian Industrial Development Strategic Plan(2013- 2025). September 2013, Addis Ababa, Ethiopia .

Economic Reform and Private Sector Development Section (ERPSDS, 2005-2015) all interactions between firms are business linkages

Tefery, H. (2016). Determinante of business linkage between small and large business in Bahirdar city, Amahara regional state.The case of Manufacturing Sector .M.SC. thesis presented to school of graduate studies of Leadstar universty College Asossa, Ethiopia.

DAB Development Research and Training PLC,(2015), An Overview of Ethiopian Manufacturing Sector: Addis Ababa Chamber of Commerce and Sectoral Association (AACCSA) Addis Ababa, Ethiopia ,October,2015.

Grant,R.M (1991) 'The Resources Based Theory of Comparative Advantage for Strategy Formulation.' California Management Review, pp. 114-135.

Premaratne, S.P. (2002). Entrepreneurial networks and small business development: The case of small enterprises in Sri Lanka. Unpublished PhD thesis. Technische Universiteit Eindhoven.

Kadushin, C. (2004). Chapter 2: Some basic network concepts and propositions, Introduction to social network theory. FDRE Ministry of Industry,(2013),Ethiopian Industrial Development Strategic Plan (2013-2025).

Ministry of urban development and construction minister, (2013), Survey on Micro and Small Enterprises (MSEs) in Selected Major Cities of Ethiopia, Addis Ababa, 2013.

Amit, R.,\&Schoemaker, P. (1993). Strategic assets and organizational rent. Strategic Management Journal, 14(1), 33-46.

Ritala, P. and Ellonen, H. (2010) 'Competitive Advantage in Inter-Firm Cooperation - Old and New Explanations.' Journal of Competitiveness Review 29(5), pp. 367-383.

Porter M, (1991). 'Towards a Dynamic Theory of Strategy'. Strategic Management Journal Winter Vol 11295 117

Porter, M.E. (1990). The Competitive Advantage of Nations. New York, NY: Free Press

Porter, M.E. (1990) 'The competitive advantage of nations.' USA, New York Free Press

Porter, M.E.( 1980) ' Competitive Strategy.' USA, New York Free Press.

UCTAD(2010) Creating Business Linkages: a Policy Perspective. New York and Geneva 
APPENDIX 1. Econometric Results of determinants of Business Linkage in Textile enterprise

\begin{tabular}{|c|c|c|c|c|c|c|}
\hline Variable Name & Coef. & Robust Std. Err. & $\mathbf{z}$ & $\mathbf{P}>\mathbf{Z}$ & Odds Ratio & Marginal Effect \\
\hline SEX & -1.095 & 0.953 & -1.150 & 0.250 & 0.334 & -0.213 \\
\hline EDUC & $0.314 * *$ & 0.137 & 2.290 & 0.022 & 1.369 & 0.057 \\
\hline AGEE & -0.168 & 0.151 & -1.110 & 0.267 & 0.846 & -0.030 \\
\hline FAMILY & -0.327 & 0.189 & -1.730 & 0.084 & 0.721 & -0.059 \\
\hline WRKC & 0.000 & 0.000 & -1.020 & 0.308 & 1.000 & 0.000 \\
\hline EMPLOYEES & 1.562 & 0.828 & 1.890 & 0.059 & 4.767 & 0.283 \\
\hline RAW & $1.972 * *$ & 0.875 & 2.260 & 0.024 & 7.188 & 0.357 \\
\hline FINANCE & $-1.280 * * *$ & 0.496 & -2.580 & 0.010 & 0.278 & -0.232 \\
\hline TECH & $1.435 * *$ & 0.698 & 2.060 & 0.040 & 4.199 & 0.260 \\
\hline INFO & 0.377 & 0.385 & 0.980 & 0.328 & 1.457 & 0.068 \\
\hline TRAIN & $-1.378 * *$ & 0.546 & -2.530 & 0.012 & 0.252 & -0.249 \\
\hline WS & 0.326 & 0.363 & 0.900 & 0.370 & 1.385 & 0.059 \\
\hline LEUP & $5.393 * * *$ & 2.078 & 2.600 & 0.009 & 219.940 & 0.794 \\
\hline LEADERS & $0.925 * * *$ & 0.349 & 2.650 & 0.008 & 2.523 & 0.167 \\
\hline INFRA & $1.002 * *$ & 0.492 & 2.040 & 0.042 & 2.724 & 0.181 \\
\hline cons & $-15.871 * * *$ & 5.576 & -2.850 & 0.004 & 0.0000001 & \\
\hline $\begin{array}{l}\text { Logistic regression } \\
\text { Wald chi2 }(15)= \\
\text { Log pseudolikelihoo }\end{array}$ & $\begin{array}{l}31.78 \\
d=-24.592602\end{array}$ & $\begin{array}{l}\text { Number of } \\
\text { Prob }>\text { chi2 } \\
\text { Pseudo R2 }\end{array}$ & $\begin{aligned} \mathrm{bs} & = \\
& = \\
& =\end{aligned}$ & $\begin{array}{c}71 \\
0.0069 \\
0.4835\end{array}$ & & \\
\hline
\end{tabular}

$* * *$ and $* *$ implies significant at $1 \%$ and $5 \%$ probability level

Source: Own Econometric Model result, 2017

APPENDIX 2. Multicollinearity Test

\begin{tabular}{|c|c|c|c|c|c|c|c|c|c|c|c|c|c|c|c|}
\hline $\begin{array}{c}\text { Varia } \\
\text { ble }\end{array}$ & $\begin{array}{l}\text { TRA } \\
\text { IN }\end{array}$ & $\begin{array}{l}\text { IN } \\
\text { FO }\end{array}$ & $\begin{array}{l}\mathrm{TE} \\
\mathrm{CH}\end{array}$ & $\begin{array}{l}\text { W } \\
\text { S }\end{array}$ & $\begin{array}{l}\text { EMPLO } \\
\text { YEES }\end{array}$ & $\begin{array}{l}\text { FINA } \\
\text { NCE }\end{array}$ & $\begin{array}{l}\text { WR } \\
\text { KC }\end{array}$ & $\begin{array}{l}\text { FAMI } \\
\text { LY }\end{array}$ & $\begin{array}{l}\text { RA } \\
\text { W }\end{array}$ & $\begin{array}{l}\text { LEAD } \\
\text { ERS }\end{array}$ & $\begin{array}{l}\text { LE } \\
\text { UP }\end{array}$ & $\begin{array}{l}\text { INF } \\
\text { RA }\end{array}$ & $\begin{array}{l}\mathrm{AG} \\
\mathrm{EE}\end{array}$ & $\begin{array}{l}\text { ED } \\
\mathrm{UC}\end{array}$ & $\begin{array}{l}\text { Mean } \\
\text { VIF }\end{array}$ \\
\hline VIF & 1.79 & $\begin{array}{c}1.6 \\
4\end{array}$ & $\begin{array}{c}1.5 \\
9\end{array}$ & $\begin{array}{l}1 . \\
51\end{array}$ & 1.39 & 1.3 & 1.29 & 1.24 & $\begin{array}{c}1.2 \\
2\end{array}$ & 1.21 & $\begin{array}{c}1.1 \\
7\end{array}$ & 1.15 & 1.1 & 1.09 & 1.34 \\
\hline $\begin{array}{c}\text { 1/VI } \\
\text { F }\end{array}$ & 0.56 & $\begin{array}{c}0.6 \\
1\end{array}$ & $\begin{array}{c}0.6 \\
3\end{array}$ & $\begin{array}{l}0 . \\
66\end{array}$ & 0.72 & 0.77 & 0.77 & 0.81 & $\begin{array}{c}0.8 \\
2\end{array}$ & 0.82 & $\begin{array}{c}0.8 \\
5\end{array}$ & 0.87 & 0.91 & 0.92 & \\
\hline
\end{tabular}

